Deborah K. Rasch MD, Leonid Bunegin BS, John Ledbetter MD, Daniel Kaminskas uD

\title{
Comparison of circle absorber and Jackson- Rees systems for paediatric anaesthesia
}

To evaluate effects of anesthesia delivery systems on respiratory work in infants, we measured end-tidlal $\mathrm{PCO}_{2}\left(\mathrm{PETCO}_{2}\right)$, transcutaneous $\mathrm{PCO}_{2}\left(\mathrm{P}_{\mathrm{c}} \mathrm{CO}_{2}\right)$ respiratory rate and arterial blood gases in infants (ages 0.2 to 23.8 months) anaesthetised with either a Jackson-Rees $(n=11$ ) or paediatric circle absorber system $(n=15)$. Two hours after induction, wish assisted ventilation there was no difference in $\mathrm{P}_{E T C} \mathrm{CO}_{2}, P_{T} \mathrm{CO}_{2}$, respiratory rave, $\mathrm{pH}$ or $\mathrm{PaCO}_{2}$ in infants anaesthetised with either system. In the laboratory, we measured inspiratory and expiratory resistances to breathing through each system at various tidal volumes and tout gas flows into the circuit. These values were compared to resistances created by breathing through an appropriately sized endotracheal tube. Alhough there was lower resistance to ventilation through Jackson-Rees system, both systems had lower resistances for almost all jlows tested than breathing through an endotracheal tube alone $(p<0.05)$. The paediatric circle absorber system is an efficient apparatus for anaesthetising spontaneously breathing infants.

The breathing circuit most commonly used to administer anaesthetic gases to the adult paticnt in the U.S.A. is the circle absorber system, ' but the use of this system for delivery of anaesthetic gases to the infant has not been widely accepted. Early investigators reported rapid patient fatigue and laboured respirations when they altempted to use the adult circle system for spontaneously breathing patients below $2-3$ years of age. ${ }^{2.3}$ These problems were attributed to increased dead spuce and high resistance

\section{Key words}

EQLIPMENT: Jackson-Rees system, breathing systems, semi-closed; ANAESTHETIC TECHNIQUES: semi-closed circle.

From the Department of Anesthesiology at The University of Texas Health Science Center, San Antonio, Texas.

Address correspondence ro: Dr. Deborah K. Rasch, Department of Anesthesiology, The University of Texas Health Science Center, 7703 Floyd Curl Drive, San Anwonio, Texas 78284-7838 valves in the system. Since that time, introduction of smaller dead space connectors, improved soda lime canisters and lower resistance valves has brought about renewed interest in the use of this system for paediatrie anaesthesia. The purpose of this study was to evaluate the effectiveness and safety of the paediatric circle system for administration of inhalational anaesthetics to spontaneously breathing infants weighing less than $10 \mathrm{~kg}$.

\section{Methods}

\section{Clinical study}

Subjects were healthy infants (weight $\leq 10 \mathrm{~kg}$ ) who presented to Medical Center Hospital (University of Texas Health Science Center at San Antonio) during a six month period for elective surgery requiring general anaesthesia. After informed consent was obtained from the parents, patients were randomly divided into two groups: Group A $(n=15)$ consisted of patients anaesthetised using a lightweight $1.5 \mathrm{~cm}$ diameter paediatric circle system (Marquest ${ }^{\text {Q }}$ ) attached to a standard adult socla lime canister and Group B $(n=11)$ included those infants anaesthetised using a Jackson-Rees modification of the Ayre's T-piece. No premedication was given. In both groups either a standard Ohio Unitrol ${ }^{*}$ or a North American Drager ${ }^{G}$ anaesthesia machine was used. Anuesthetic maintenance was accomplished with either halothane or isoflurane, at inspired concentrations of 1.1-1.3 MAC such that anaesthetic depth was not significantly different between groups. Ventilation was assisted by the anaesthetist four times per minute to a peak inspiratory pressure of $15-20 \mathrm{~cm} \mathrm{H}_{2} \mathrm{O}$ in an otherwise spontaneously breathing infant. Inspired oxygen concentrations ranged from 40-50 per cent and no muscle relaxants were given. Once induction was completed, the fresh gas flow rate was adjusted until a minimum flow was reached which both compensated for a leak around the endotrachcal tube (auscultated between a peak inspiratory pressure of 12-15 $\mathrm{cm} \mathrm{H}_{2} \mathrm{O}$ ) and prevented significant rebreathing of exhaled gases (inspired $\mathrm{PCO}_{2} \leq 0.15$ per cent) to reduce heat and fluid losses from the respiratory tract. All patients were monitored with automatic blood pressure monitor (Dina- 
TABLE I Pcak flow tates

\begin{tabular}{lll}
\hline $\begin{array}{l}\text { Tidal volume } \\
(\mathrm{V} t)\end{array}$ & $\begin{array}{l}\text { Peakinspiratory } \\
\text { flow rate }\end{array}$ & $\begin{array}{l}\text { Peak expiratory } \\
\text { flow rase }\end{array}$ \\
\hline $20 \mathrm{ml}$ & $25 \mathrm{ml} \cdot \mathrm{sec}^{-1}$ & $16.7 \mathrm{ml} \cdot \mathrm{sec}^{-1}$ \\
$40 \mathrm{ml}$ & $50 \mathrm{ml} \cdot \mathrm{sec}^{-1}$ & $33.3 \mathrm{ml} \cdot \mathrm{sec}^{-1}$ \\
$60 \mathrm{ml}$ & $75 \mathrm{ml} \cdot \mathrm{sec}^{-1}$ & $50 \mathrm{ml}-\mathrm{sec}^{-1}$ \\
$80 \mathrm{ml}$ & $100 \mathrm{ml} \cdot \mathrm{scc}^{-1}$ & $66.7 \mathrm{ml} \cdot \mathrm{sec}^{-1}$ \\
$100 \mathrm{ml}$ & $125 \mathrm{ml} \cdot \mathrm{sec}^{-1}$ & $83.3 \mathrm{ml} \cdot \mathrm{sec}^{-1}$ \\
\hline
\end{tabular}

Flow rates for each tidal volume ucre calculated at the peak of inspiration or expiration by the following formulas assuming a constant RR of $30 \cdot \mathrm{min}^{-1}$.

Peak expiratory flow rate $=$ VuExp. time; Exp. time at $I: E$ I:1.5 = $1.2 \mathrm{sec}$.

Peak inspiratory flow rate $=$ Vu/Insp. time; Insp_time at I:E of 1:1.5 = $0.8 \mathrm{sec}$.

mapp ${ }^{(5)}$ ), ECG, precordial stethoscope, and rectal temperature probe. In addition, inspired $\mathrm{PCO}_{2}\left(\mathrm{PiCO}_{2}\right)$ and end tidal $\mathrm{PCO}_{2}\left(\mathrm{PETCO}_{2}\right)$ were monitored continuously by means of a mass spectrometer (Perkins-Elmer ${ }^{B}$ ). A transcutaneous probe (Sensor-Medics ${ }^{9}$ ) to monitor $\mathrm{PCO}_{2}$ $\left(\mathrm{P}_{\mathrm{rCCO}}\right)$ was also applied to the skin. Intraoperative temperatures, $\mathrm{PrCCO}_{2}, \mathrm{PJCO}_{2}$ and $\mathrm{PETCO}_{2}$ were recorded every 15 minutes by an independent observer. Serial arterial blood gases $(n=10$ for Group $A$ and $n=8$ for Group B patients) were also obtained on an hourly basis. Differences in mean values for $\mathrm{pH}, \mathrm{PCO}_{2}$, base excess, as well as $\mathrm{PETCO}_{2}$, and $\mathrm{PTcCO}$ were analysed by a $\$$ tudentNeuman-Keuls $t$ test for significance. Significance was taken to be $p<0.05$.

\section{Laboratory study}

Inspiratory and expiratory resistances were then measured in the laboratory using the following model. Each system (the Jackson-Rees modification of the Ayre's $T$ piece and the paediatric circle absorber system) was attached to a Harvard small-animal ventilator. This arrangement allowed exact tidal volumes and flow rates to be adjusted for calculation of resistance. A pressure port was placed alternately in the inspiratory and expiratory limbs of the circle system, as well as bchind the elbow of the Jackson-Rees system to measure peak inspiratory and expiratory pressures generated by the ventilator. The pressure transducer was a Statham P23 1.D. transducer connected to a Model 7P122B preamp amplifier within a 7D-Grass polygraph. All measurcments were made with a $500 \mathrm{ml}$ bag in each system and the "pop-off' valves of both circuits were maintained in the full open position because not only would this closely approximate the clinical circumstances of an intubated spontancously breathing infant, but also for reasons of standardisation of conditions for comparison of the two circuits.

The inspiratory to expiratory ratio on the ventilator was set at 1 to 1.5 with a constant respiratory rate of 30 breaths $\cdot \mathrm{min}^{-1}$. Tidal volumes (Vt) were varied on each system at increments of $20 \mathrm{ml}$ each to a maximum of 100 $\mathrm{ml}$ tidal volume, and peak flow rates were calculated for each tidal volume (Table I). Resistance was then calculated by measuring expiratory or inspiratory pressure peaks for ten determinations each djvided by peak flow rate: (Resistance $=$ Peak pressure/peak flow rate.) Resistance measurements were made initially with total flow through the circle system at $5 \mathrm{~L} \cdot \mathrm{min}^{-1}$ after which the measurements were repeated at several points during progressive lowering of the total flow to $0.4 \mathrm{~L} \cdot \mathrm{min}^{-1}$. Resistance calculations were done on the Jackson-Rees system for cach tidal volume at a total flow rate of 2.5 times minute ventilation as suggested by Harrison, ${ }^{4}$ then repeated calculations were done at flow rates of $1-5 \mathrm{~L} \cdot \mathrm{min}^{-1}$. For comparison, inspiratory and expiratory resistances were also measured at the distal tip of several appropriate sized endotracheal tubes open to air at the following tidal volumes: $20 \mathrm{ml} V \mathrm{t}$ via a $3.0 \mathrm{~mm}$ endotracheal tube; $40 \mathrm{ml}$ Vt via a $3.5 \mathrm{~mm}$ endotracheal tube; $60 \mathrm{ml}$ Vt via a $4.0 \mathrm{~mm}$ endotracheal tube, 80 and $100 \mathrm{ml}$ Vt via a 4.5 endotracheal tube.

Data were analysed by analysis of variance, followed by a Student-Neurnan-Keuls post test for significance between specified points. Significance was taken at $\mathrm{p}<$ 0.05

\section{Results}

Clinical study

A comparison of patient characteristics is shown in Table II. Age, wcight, and length of anaesthetic were similar in both groups. However, the minimum total litre gas flow used to administer the anaesthetic was significantly lower $(P<0.001)$ for Group A patients compared to those of Group B. $\mathrm{PETCO}_{2}$ and $\mathrm{PTC}_{6} \mathrm{CO}_{2}$ measurements (Table III) were not statistically different between the two groups at any of the times recorded. Likewise, respiratory rate,

TABLE If Group characteristics

\begin{tabular}{lll}
\hline & $\begin{array}{l}\text { Crorp A } \\
\text { Paediatric circh } \\
\text { absorber } \\
\text { system } \\
n=15\end{array}$ & $\begin{array}{l}\text { Group B } \\
\text { Jackson-Rees } \\
\text { system } \\
n=I J\end{array}$ \\
Variable & 8.9 & 10.4 \\
\hline Mean Age (months) & $(0.2$ to 18.3 mos) & $\langle 0.32$ to 23.8 mos) \\
(range) & $7.08 \pm 3.15$ & $6.1 \pm 3.4$ \\
Weight (kg) & $2.4 \pm 1.4$ & $4.7 \pm 0.92^{*}$ \\
Total gas flow (L.min ${ }^{-1}$ ) & $1.6 \pm 0.71$ & $2.1 \pm 0.39$ \\
Length of anaesthetic (hours)
\end{tabular}

All values are reponed as mean \pm SD.

${ }^{*} \mathrm{p}<0.05$. 


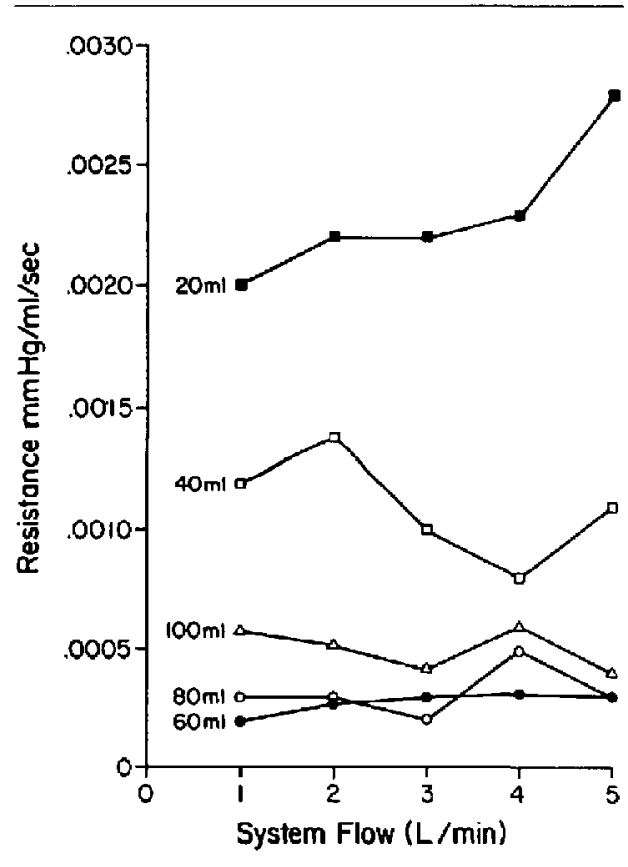

FIGURE I Changes in inspiratory ressistance of Jackson-Rees circuit with inereasing total system flow.

arterial $\mathrm{pH}, \mathrm{PCO}_{2}$ and base excess values were similar in both groups. There was no significant difference in rectal temperatures of patients anacsthetiscd with cither of the two systems up to two hours after the start of the anaesthetic.

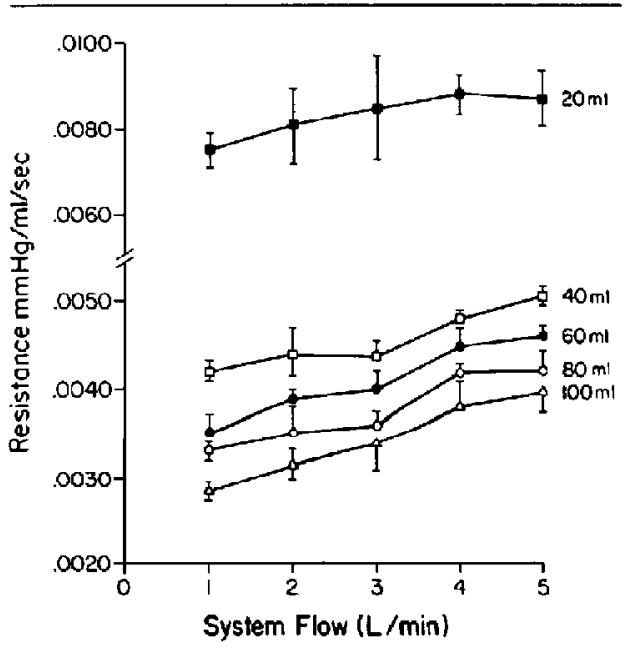

FIGURE 2 Changes in expiratory resistance of Jackson-Rees circuit with increasing total system flow.

\section{Laboratory study}

Resistance to expiration and inspiration through the Jackson-Rees system at varying tatal system flows is shown in Figures 1 and 2. Inspiratory resistance showed little change in response to increasing total system flows for all tidal volumes, although slightly higher resistance to inspiration was noted for the 20 and $40 \mathrm{ml}$ tidal volumes. A similar pattern was also noted for expiratory resistance measurements on the Jackson-Rees system. Resistance values for the circle system are represented in Figures 3 and 4 . Similar to the values obtained for the Jackson-Rees

TABLE IIl Blood gas data, mean - SEM

\begin{tabular}{|c|c|c|c|c|c|c|c|c|c|}
\hline & & \multicolumn{8}{|c|}{ Time (minutes) } \\
\hline & & 15 & 30 & 45 & 60 & 75 & 90 & 105 & 120 \\
\hline \multirow{4}{*}{$\begin{array}{l}\text { Group A } \\
\text { (Paediatric circle } \\
\text { absorber system) }\end{array}$} & PETCO & $37.9 \pm 1.4$ & $37.4 \pm 1.6$ & $39.3=1.6$ & $39.7 \pm 1.8$ & $40.2 \pm 1.2$ & $40.8 \pm 1.1$ & $40.7 \pm 0.5$ & $37,4 \pm 1,3$ \\
\hline & $\begin{array}{l}\mathrm{PTcCO}_{2} \\
\mathrm{pH}\end{array}$ & $37.3 \pm 0.21$ & $40.0 \pm 0.91$ & $42.2 \pm 1.7$ & $\begin{array}{l}43.2 \pm 1.2 \\
7.33 \pm 0.01\end{array}$ & $41.2 \pm 0.41$ & $41.3 \pm 0.3$ & N:A & $\begin{array}{l}\text { N/A } \\
7.34 \pm 0.005\end{array}$ \\
\hline & $\mathrm{PCO}_{2}$ & & & & $38.2=1.4$ & & & & $43 \pm 1$ \\
\hline & $\mathrm{BE}$ & & & & $-4.5 \pm 0.9$ & & & & $-4.5 \pm 0.5$ \\
\hline \multirow{4}{*}{$\begin{array}{l}\text { Group B } \\
\text { (Jackson-Rees } \\
\text { system) }\end{array}$} & $\mathrm{PTcCO}_{2}$ & $38.8 \pm 2.1$ & $40.1 \pm 0.67$ & $38.1 \pm 1.9$ & \pm 1.7 & $37.6 \pm 1.8$ & $39.3 \pm 2.1$ & $42 \pm 2$ & $42.6 \pm 2.4$ \\
\hline & $\begin{array}{l}\mathrm{PTcCO}_{2} \\
\mathrm{pH}\end{array}$ & $39.8 \pm 0.87$ & $40.8 \pm 0.95$ & $39.3 \pm 0.95$ & $\begin{array}{c}40.5 \pm 1.2 \\
7.37 \pm 0.03\end{array}$ & $41.5 \pm 0.28$ & $41.6=0.57$ & N'A & $\begin{array}{l}\text { N/A } \\
7.34=0.03\end{array}$ \\
\hline & $\mathrm{PCO}_{2}$ & & & & $37.8=2.5$ & & & & $42 \pm 2.3$ \\
\hline & $\mathrm{BE}$ & & & & $-3 \pm 2.1$ & & & & $-4.3 \pm 1.1$ \\
\hline
\end{tabular}

N/A Insufficient data available for computation. 


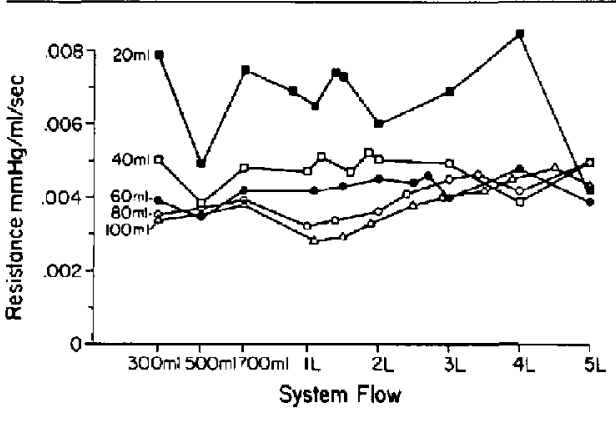

FIGURE 3 Changes in inspiratory resistance of paediatric circle absorber system with increasing total system now.

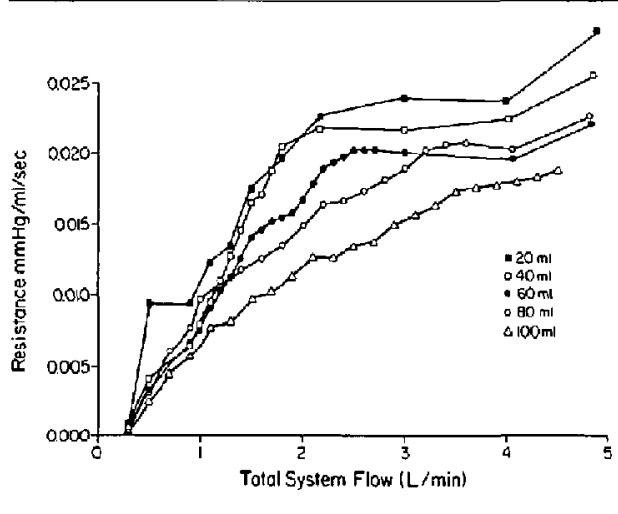

FIGURE 4 Changes in explratory resistance of paediatric circle absorber system with increasing total systcm flow.

system, inspiratory resistances for the circle system measured at various tidal volumes were relatively constant for each tidal volume regardless of total system flow. However, expiratory resistances increased dramatically as system flow was increased through the circle system. This increase appeared to be determined by the limited capacity of the "pop-off" valve to handle the increascd flow.

Figures 5 and 6 show inspiratory and expiratory resistances measured for each endotracheal tube alone (sizes 3.0-4.5 mm) at various tidal volumes compared to that of the Jackson-Rees and circle systems at the mean flow rates actually used for our clinical studies. Specific tidal volumes were chosen for each tube size based on the principle that a $20 \mathrm{ml} \mathrm{Vt}$ represents a $2 \mathrm{~kg}$ infant who would be most appropriately intubated with a $3.0 \mathrm{~mm}$ endotracheal tube, etc. Although there was a statistically

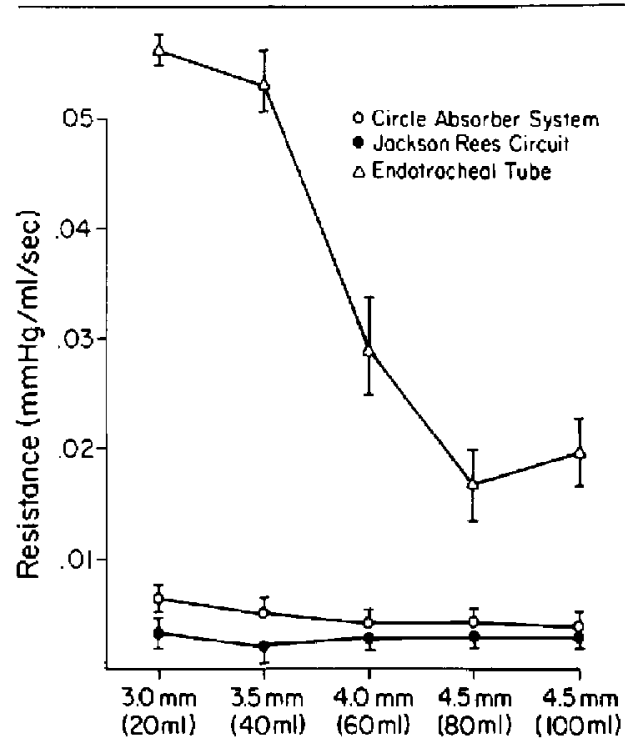

Endotracheal tube size (tidal volumes)

FIGURE 5 Inspiratory resistance of circle and Jackson-Rees systems compared to inspiratory resistance of various sizes of endotrachea! tubes.

significant difference $(p<0.05)$ between both inspiratory and expiratory resistances to breathing through the circle system compared to the Jackson-Rees system, all inspiratory resistances measured for both systems were approximately ten times less than the resistance to breathing through an endotracheal tube alone at the same tidal volume. Expiratory resistances were also significantly lower $(p<0.05)$ for almost all measurements on both systems, although at an $80 \mathrm{ml}$ tidal volume through a 4.5 $\mathrm{mm}$ endotracheal tube resistance to expiration on the circle system was slightly higher although not statistically significant.

\section{Discussion}

The breathing system most often used for adult anaesthesia in the U.S.A. in recent years has been the circle absorber system; ${ }^{1}$ however, the use of this system for delivery of anaesthetic gases to the infant has not been widely accepted in practice. Instead, the Jackson-Rees modification of the Ayre's T-piece has been most commonly utilised because it is a valveless system which is postulated to minimise the incidence of rebreathing of expired gases and to reduce respiratory work in the 


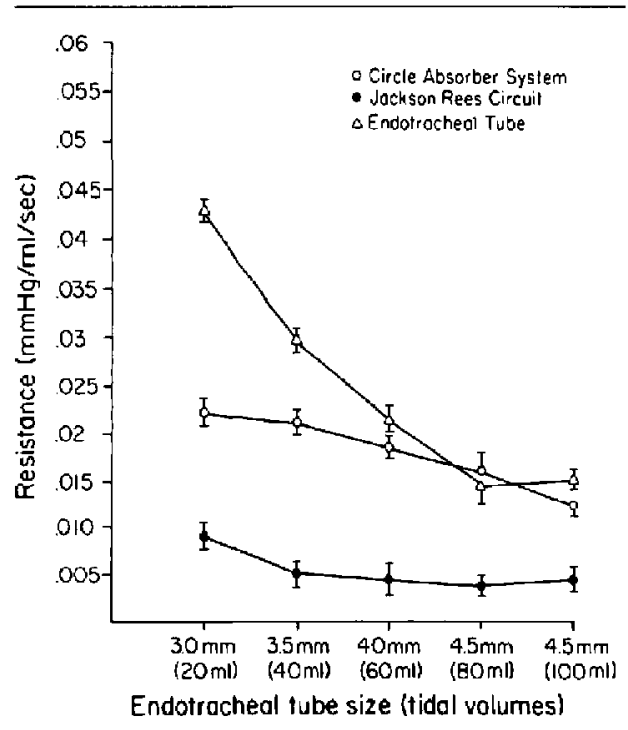

FIGURE 6 Expiratory ressistance of circle and Jackson-Rees systems compared to expiratory resistance of various sizes of endotracheal tubes.

spontaneously breathing infant. This system has the disadvantage of being rather bulky and sometimes difficult to stabilise without placing traction on the endotracheal tube, especially when scavenging equipment is attached. Unless a humidifier is used in this system, the high-flow rates requircd to prevent rebreathing causes significant heat loss and desiccation of pulmonary secretions. Effective scavenging of expired gases is also difficult and cumbersome with the Jackson-Rees system. On the other hand, previous investigators have reported early patient futigue and laboured respiration when they attempted to use the adult circle system in young patients. ${ }^{2,3}$

Since that time several modifications of the circle system for pacdiatric use have been proposed, but all have required either the purchasing of special equipment or revision of existing anaesthesia machines for their use. ${ }^{5-9}$ However, with the introduction of lower resistance valves, improved soda lime canisters, and smaller dead space connectors, use of a much less complicated paediatric circle system has been made possible. Graff et al., ${ }^{10}$ showed that infants anaesthetised with nitrous oxide and halothane had similar arterialised capillary blood gas values after 15 minutes of spontaneous ventilation using either the Jackson-Rees or several different infant circle systems. Ver Steeg and Stevens ${ }^{11}$ demonstrated that there was no difference in the respiratory effort of infants anaesthetised with an infant circle system compared to the Jackson-Rees

Therefore, to address the questions of dead space and rebreathing of expired gases, we measured both inspiratory and end-tidal $\mathrm{PCO}_{2}$ in addition to $\mathrm{PaCO}_{2}, \mathrm{pH}$, and respiratory rate in our series of patients. At a flow rate of $1.0-3.8$ $\mathrm{L} \cdot \mathrm{min}^{-1}$ using a paediatric circle system, inspired $\mathrm{PCO}_{2}$ was easily maintained below 0.15 per cent and was no different from those values recorded for patients anaesthetised with the Jackson-Rees system. Also $\mathrm{PETCO}_{2}$ and $\mathrm{PTCCO}_{2}$ were equivalent between the two groups. For those patients where arterial blood gas data were available (Table III), there was no significant difference in $\mathrm{pH}$ or base excess between the two groups, which when combined with the fact that respiratory rates were the same suggests that the work of breathing was not clinically different for infants anaesthetised with either system. $\mathrm{PlCO}_{2}$ measurements alleviate the concern that significant rebreathing of expired gases might occur that would prohibit use of the paediatric circle absorber system in smatl infants.

To support these clinical observations, inspiratory and expiratory resistances were measured in the laboratory at various tidal volumes and system flow rates for both circuits. Although inspiratory resistances were slightly greater for the circle system than the Jackson-Rees system, these resistance measurements were consistently much lower than those of the endotracheal tube alone. Expiratory resistances were also generally lower for both circuits compared to the endotracheal tube alone, although to a lesser degree. We concluded, therefore, that since the major energy expending component of the respiratory cycle is inspiration ${ }^{12}$ and the system itself contributed relatively little to the total system inspiratory resistance, the patient's work of breathing should not be significantly increased by one system over the other. This conclusion is substantiated by the fact that in our clinical investigation, respiratory rate, $\mathrm{PETCO}, \mathrm{PTcCO}_{2}$, base deficit, and $\mathrm{pH}$ were not significantly different in the patients breathing through the circle system compared to those breathing through the Jackson-Rees system.

Both circuits exhibited increasing resistances to expiration as the total flow through the system was increased. This was much more dramatic with the circle system when flows achieved $1-1.5$ times minute ventilation, and seemed to be related to the limited capacity of the "popoff" valve on the Ohio Unitrol anaesthesia machine to accommodate the increased flow. This phenomenon was also noted with the Jackson-Rees system, although to a lesser degree. Also, in the laboratory it was observed that if the "pop-off" valve was closed slightly on the JacksonRees system to allow assisted ventilation of the patient as would be done in practice, the expiratory resistances in- 
creased six-to ten-fold and were greater than those of the circle system for the same tidal volume and total system gas flows.

The presence of adequately functioning valves within the circuit is a requirement for using the circle absorber system to anaesthetise young patients. An expiratory valve that does not properly close at the end of exhalation might lead to hypercarbia due to excessive rebreathing. Inspiratory valve malfunction could produce an increased work of breathing should it hesitate to open as the infant tries to inhale. Therefore, the machine should be inspected carefully at regular intervals to assure that these compouents are functioning properly.

In our clinical study, assisted ventilation was used in the young infant rather than allowing them to spontaneously breathe throughout the procedure primarily due to our concerns over respiratory depression produced by the inhalational anaesthetics. Functional residual capacity (FRC) has been shown to fall by 40 per cent of preinduction levels in neonates breathing 1 MAC halothane. In addition, minute ventilation has been shown to decrease as much as 37 per cent with a concomitant rise in $\mathrm{PaCO}_{2}$ regardless of the anaesthesia delivery system. ' Therefore to prevent atelectasis and help conserve minute ventilation assisted ventilation was used.

In regard to cost, a much lower fresh gas flow (FGF) was used with the circle system, significantly decreasing the volume of inhalational agent vaporised per unit time and hence the anaesthetic cost of volatile agents. For example, the FGF for patients anaesthetised using the paediatric circle system was $2.4 \pm 1.4 \mathrm{~L} \cdot \mathrm{min}^{-1}$ compared to the Jackson-Rees system which was $4.7 \pm 0.92$ $\mathrm{L} \cdot \mathrm{min}^{-1}$. This would result in an average savings of 1.98 $\mathrm{ml}$ of halothane liquid, $1.62 \mathrm{ml}$ of enflurane liquid, or 2.2 $\mathrm{ml}$ of isoflurane liquid every hour, based on a steady state anaesthetic concentration of one per cent.

In conclusion, the modern paediatric circle absorber system is a safe and efficient method for delivery of anaesthetic gases to the infant. With regard to cost, it offers some advantages over the Jackson-Rees system due to lower volumes of agent vaporised per unit time. Heat and fluid conservation are also promoted by the low flows, and with more efficient scavenging equipment available for the circle system, there is less contamination of the operating room environment.

\section{References}

1 Gregory GA. Pediatric Anesthesia. Churchill Livingstone. 1983, Chapters $l$ and l0, pp. 5, 362.

2 Stephen $C R$, Slater $H M$. Agents and techniques employed in pediatric anesthesia. Anesth Analg 1950; 20: 254-

62.
3 Adriani J, Griggs T. Rebreathing in pediatric anesthesia: recommendations and descriptions of improvements in apparatus. Anesthesiology 1953; 14: 337-47.

4 Harrison $G A$. Ayre's T-piece: a review of its modifications. Br. J Anaesth 1964; 36: 113.

5 Revell $P G$. A circulator to eliminate meshanical dead space in circle absorption systems. Can Anaesth Soc J 1959; 6: 98-103.

6 Roffey PJ, Revell DG, Morris LE. An assessment of the Revell circulator. Anesthesiology 1961, 22: 583-90.

7 Bloomquist ER. Pediatric circle absorber. Anesthesiology 1958; 18: 787-9.

8 Cullen SC. Current comment and case reports. Pediatric circle absorber. Anesthesiology 1957; 18: 787-90.

$9 \mathrm{McDonald} / H$. A circle absorber for infants. $\mathrm{Br} \mathrm{J}$ Anaesth $1961 ; 33: 58-9$.

10 Graff TD, Holzman RS, Benson DW. Acid-base balance infants during halothane ancsthesia with usc of an adult circle-absorption system. Anesth Analg 43: 583-9; 1964.

11 Ver Steeg J. Sievens WC. A comparison of tespiratory effort of infants anesthetized with several adult and pediatric systems. Anesthesiology 1966; $27: 229$.

12 Gryton AC. Textbook of Medical Physiology, W.B Saunders Co. Chap 39, 1971, pp 456-7.

Résumé

Afin d'évaluer les effets des systèmes anesthésiques sur le travail respiratoire chez les enfants on a mesuré la $\mathrm{PCO}_{2}$ en fin d'expiration $\left(\mathrm{PtrCO}_{2}\right)$, la $\mathrm{PCO}_{2}$ transcutanée $\left(\mathrm{PTCO}_{2}\right)$, la fréquence respiratoire er les gaz artérieis chez les enfants (ages 0.2 a 23.8 mois) anesthésiés soit avec un système Jackson-Rees $(n=1)$, ou un système de circuit pédiatrique avec absorbeur de $\mathrm{CO}_{2}(n=15)$. Dewx heures après l'itduction en respiration arsistée il $n$ y avait aucune différence dans la $\mathrm{PETCO}_{2}, \mathrm{PT}_{5} \mathrm{CO}_{2}$ la fréquence respiratoire, $\mathrm{pH}$ ou la $\mathrm{PaCO}_{2}$ chez les enfants anesthésiés avec l'un ou l'autre des systènes. Au laboratoire on a mesuré les résistances inspiratoures et expiratoires de ces systèmes avec des volumes courants et des débits variables dans le circuit. Ces valeurs sont comparées à la résistance créée en respirant à travers un tube endotrachéal approprié d'egale grosseur. Même si on a noré des plas basses résistances à travers le système de Jackson-Rees, tous les deux systèmes offraient des résistances aussi basses a tous les flots évalués lors de la respiration à travers un tube endotrachéal seul $(p<0.05$ ). Le circuit pédiatrique avec absorbeur de $\mathrm{CO}_{2}$ est efficace pour anesthésier des enfants en respiration sponsanée. 